\title{
FAKTOR-FAKTOR RISIKO MALARIA DI WILAYAH KERJA PUSKESMAS PARUGA KOTA BIMA NUSA TENGGARA BARAT
}

\author{
Irma Rubianti, Trisno Agung Wibowo, Solikhah. \\ Fakultas Kesehatan Masyarakat, Universitas Ahmad Dahlan, Yogyakarta
}

\begin{abstract}
Background: Malaria is one of reemerging diseases and ranked in $10^{\text {th }}$ position as deadly diseases. Malaria is also the $5^{\text {th }}$ deadly infective disease in the world. Malaria is tropical disease that been main cause of death, each year $40 \%$ of world inhabitant have risk of malaria disease or approximately 300 - 500 million of cases. About $1-3$ millions of people died because of malaria each year. In Indonesia, about $50 \%$ of Indonesian people live in malaria endemic area. According to WHO, not less than 30 million cases of malaria occurs each year in Indonesia about 30.000 people were died. This study is purposed to recognize risk factors in relation with malaria incident in working area of Paruga Puskesmas (Public Health Service), Bima City, of Nusa Tenggara Barat.

Methods: This was analytic-observational research using case-control approach. Sampling was performed in a way of purposive sampling. Cases in this study were malaria sufferer, who takes medical care in Puskesmas of Paruga and those who counted to Mass Blood Survey program on May, 2008. Control was another diseases sufferer who takes medical care in Puskesmas of Paruga and not suffers malaria according to Mass Blood Survey as shown in laboratory examination result.

Results: There was relation between distance of house, mosquito's propagation place as well as mosquito's shelter and malaria incident as seen from $O R=5,41, C l=1,38<O R<24,81, p=0,001$. There was no relation between habit of setting mosquito net and malaria incident as seen from $O R=1,00$, $C l=0,52<O R<1,94, p=1,00$. There was relation between habit of setting mosquito essence and malaria incident as seen from $\mathrm{OR}=2,25, C l=1,05<\mathrm{OR}<3,88, p=0,023$. There was no relation between habit of going out at night and malaria incident as seen from $O R=1,67, C l=0,73<O R<3,82$, $p=0,184$. There was relation between knowledge and malaria incident as seen from $O R=1,99$, $C l=1,02<O R<3,88, p=0,029$. There was no relation between malaria elucidation and malaria incident as seen from $O R=0,94, C l=0,43<O R<2,03, p=0,855$.

Conclusion: Distance of house, mosquito's propagation place as well as mosquito's shelter, habit of setting mosquito net, and knowledge was malaria risk factors in working area of Paruga Puskesmas (Public Health Service), Bima City, of Nusa Tenggara Barat.
\end{abstract}

Keywords: Risk factors, malaria, Puskesmas of Paruga (Paruga Public Health Service)

\section{PENDAHULUAN}

Saat ini malaria merupakan penyakit yang timbul kembali (reemerging disease) dan menempati urutan ke-10 penyebab kesakitan. Malaria juga menduduki urutan ke-5 dari enam penyakit infeksi yang menjadi penyebab kematian di dunia ${ }^{1}$. Malaria merupakan penyebab kematian utama penyakit tropik, setiap tahun sekitar $40 \%$ penduduk di dunia berisiko menderita penyakit malaria atau sekitar 300-500 juta kasus. Diperkirakan 1-3 juta penduduk dunia setiap tahunnya meninggal karena penyakit malaria. Kasus kematian karena malaria berat di Indonesia masih cukup tinggi yaitu antara $20,9-50 \%{ }^{2}$.

Di Indonesia, diperkirakan 50\% penduduk Indonesia masih tinggal 'di daerah endemis malaria. Menurut perkiraan World Health Organization (WHO), tidak kurang dari 30 juta kasus malaria terjadi setiap tahunnya di Indonesia, dengan 30.000 kematian. Survai kesehatan nasional tahun 2001 mendapati angka kematian akibat malaria sekitar 8-11 per 100.000 orang per tahun. Berdasarkan Survei Kesehatan Rumah Tangga 1995, diperkirakan 15 juta penduduk Indonesia menderita malaria, 30 ribu diantaranya meninggal dunia. Morbiditas (angka kesakitan) malaria sejak tiga tahun terakhir menunjukkan peningkatan. Di Jawa dan Bali terjadi peningkatan: dari 18 
kasus per 100 ribu penduduk (1998) menjadi 48 kasus per 100 ribu penduduk (2000). Survei Kesehatan Rumah Tangga (SKRT) tahun 2001 memperkirakan angka kematian spesifik akibat malaria di Indonesia adalah 11 per 100.000 untuk laki-laki dan 8 per 100.000 untuk perempuan.

Di Nusa Tenggara Barat (NTB) khususnya di Kota Bima kasus malaria masih cukup tinggi, hal ini dapat kita lihat dari jumlah kasus malaria yang tercatat di wilayah kerja Puskesmas Paruga Kota Bima. Berikut data jumlah kasus Malaria di Kota Bima di wilayah kerja Puskesmas Paruga periode Januari-Desember 2007.

Tabel 1. Jumlah Kasus Malaria di Wilayah Kerja Puskesmas Paruga Kota Bima Nusa Tenggara Barat Periode Januari-Desember 2007

\begin{tabular}{|c|c|c|c|c|c|c|c|c|c|c|c|c|c|c|}
\hline \multirow{2}{*}{$\mathrm{No}$} & \multirow{2}{*}{ Wilayah } & \multicolumn{12}{|c|}{ Bulan } & \multirow{2}{*}{ Total } \\
\hline & & 1 & 2 & 3 & 4 & 5 & 6 & 7 & 8 & 9 & 10 & 11 & 12 & \\
\hline 1 & Paruga & 140 & 117 & 149 & 257 & 225 & 133 & 138 & 184 & 105 & 105 & 169 & 148 & 1.870 \\
\hline 2 & Tanjûng & 52 & 67 & 67 & 129 & 109 & 76 & 58 & 68 & 38 & 44 & 53 & 72 & 833 \\
\hline 3 & Sarae & 41 & 40 & 49 & 117 & 86 & 37 & 40 & 68 & 33 & 39 & 83 & 57 & 690 \\
\hline 4 & $\mathrm{Nae}$ & 40 & 51 & 53 & 82 & 78 & 34 & 40 & 58 & 45 & 30 & 58 & 49 & 618 \\
\hline 5 & Sambi Nae & 23 & 10 & 30 & 57 & 65 & 26 & 20 & 23 & 28 & 41 & 45 & 22 & 390 \\
\hline
\end{tabular}

Dari Tabel 1 dapat dilihat bahwa kejadian malaria di Kota Bima masih tinggi dengan nilai Annual Malaria Incidence (AMI) sebesar 153 kasus per 1000 penduduk. Tingginya angka kejadian malaria di Kota Bima menurut teori disebabkan oleh beberapa faktor yaitu antara lain: lingkungan, kebiasaan masyarakat, tingkat pengetahuan masyarakat dan pelayanan kesehatan ${ }^{3}$.

Fenomena tersebut merupakan latar belakang bagi peneliti untuk melakukan penelitian tentang "Faktor-faktor Risiko Malaria di Wilayah Kerja Puskesmas Paruga Kota Bima Nusa Tenggara Barat".

Alasan peneliti memilih Puskesmas Paruga sebagai tempat penelitian karena wilayah kerja Puskesmas Paruga merupakan daerah endemis malaria dengan kasus yang tinggi dengan $A M I$ sebesar 153 kasus per 1000 penduduk, dengan tujuan untuk mengetahui faktor-faktor risiko yang berhubungan dengan kejadian malaria di wilayah kerja Puskesmas Paruga Kota Bima Nusa Tenggara Barat.

\section{METODE PENELITIAN}

Penelitian ini menggunakan rancangan penelitian analitik observasional dengan pendekatan kasus-kontrol. Populasi dalam penelitian ini adalah seluruh pasien yang berobat di Puskesmas Paruga dan masyarakat yang termasuk dalam program Mass Blood Survey pada bulan Mei 2008. Sampel penelitian untuk kasus adalah penderita malaria yang berobat di Puskesmas Paruga dan penderita malaria yang termasuk dalam program Mass Blood Survey pada bulan Mei 2008, dengan kriteria inklusi: umur 15-55 tahun, bersedia menjadi subjek penelitian, bertempat tinggal di daerah penelitian, dan kriteria eksklusi: tidak bersedia menjadi subjek penelitian, tidak bertempat tinggal tetap 2 minggu sebelum sakit.

Sampel penelitian pembanding (kontrol) adalah penderita penyakit lain selain malaria yang yang berobat di Puskesmas Paruga dan yang tidak menderita malaria menurut program Mass Blood Survey ditunjukkan dari hasil pemeriksaan laboratorium dan bersedia menjadi responden dengan umur yang sama dengan kasus dengan selisih umur enam bulan. Besar sampel menggunakan rumus ${ }^{14}$ yang berjumlah 83 . Perbandingan sampel kasus dan kontrol 1:1 sehingga jumlah sampel seluruhnya 166 orang. Teknik pengambilan sampel secara purposive sampling. 
Pengumpulan data digunakan: kuesioner, dan lembar pengamatan (check list). Data dianalisis menggunakan uji chi square dan digunakan OR (Odds rasio) untuk mengetahui seberapa besar hubungan variabel bebas terhadap variabel terikat.

\section{HASIL PENELITIAN DAN PEMBAHASAN}

\section{a. Analisis Univariat}

1) Karakteristik subyek berdasarkan umur kelompok umur, jenis kelamin, pendidikan dan pekerjaan disajikan pada tabel 2

Tabel 2. Distribusi frekuensi karakteristik subyek penelitian berdasarkan kelompok umur, jenis kelamin, pendidikan dan pekerjaan di wilayah kerja Puskesmas Paruga tahun 2008

\begin{tabular}{|c|c|c|c|c|c|}
\hline \multirow[t]{2}{*}{ No } & \multirow[t]{2}{*}{ Variabel } & \multicolumn{2}{|c|}{ Kasus } & \multicolumn{2}{|c|}{ Kontrol } \\
\hline & & Jumlah & $(\%)$ & Jumlah & $(\%)$ \\
\hline \multirow[t]{6}{*}{1} & Umur & & & & \\
\hline & $15-24$ & 30 & 36,1 & 30 & 36,1 \\
\hline & $25-34$ & 29 & 34,9 & 29 & 34,9 \\
\hline & $35-44$ & 12 & 15,4 & 12 & 15,4 \\
\hline & $\geq 45$ & 12 & 14,5 & 12 & 14,5 \\
\hline & Total & 83 & 100 & 83 & 100 \\
\hline \multirow[t]{4}{*}{2} & Jenis Kelamin & & & & \\
\hline & Laki-laki & 34 & 41,0 & 32 & 38,6 \\
\hline & Perempuan & 49 & 59,0 & 51 & 61,4 \\
\hline & Total & 83 & 100 & 83 & 100 \\
\hline \multirow[t]{7}{*}{3} & Pendidikan & & & & \\
\hline & PT & 5 & 6,0 & 1 & 1,2 \\
\hline & SMA & 42 & 50,6 & 28 & 33,7 \\
\hline & SMP & 20 & 24,1 & 23 & 27,7 \\
\hline & SD & 14 & 16,9 & 30 & 36,1 \\
\hline & TS & 2 & 2,4 & 1 & 1,2 \\
\hline & Total & 83 & 100 & 83 & 100 \\
\hline \multirow[t]{12}{*}{4} & Pekerjaan & & & & \\
\hline & Buruh & 4 & 4,8 & 7 & 8,4 \\
\hline & IRT & 21 & 25,3 & 32 & 38,6 \\
\hline & Mahasiswa & 5 & 6,0 & 1 & 1,2 \\
\hline & Nelayan & 2 & 2,4 & 1 & 1,2 \\
\hline & Tukang ojek & 3 & 3,6 & 1 & 1,2 \\
\hline & Pelajar & 9 & 10,8 & 9 & 10,8 \\
\hline & Petani & 2 & 2,4 & 1 & 1,2 \\
\hline & PNS & 2 & 2,4 & 22 & 26,5 \\
\hline & Wiraswasta & 32 & 38,6 & 7 & 8,4 \\
\hline & Tidak bekerja & 3 & 3,6 & 9 & 10,8 \\
\hline & Total & 83 & 100 & 83 & 100 \\
\hline
\end{tabular}

Berdasarkan hasil penelitian di wilayah kerja puskesmas paruga, subyek pada kelompok umur terdiri dari 83 kasus dan 83 kontrol dengan menggunakan perbandingan 1:1. Karakteristik subyek menurut umur yang paling banyak menderita malaria di wilayah kerja Puskesmas Paruga adalah yang berumur 1524 tahun yaitu sebanyak 30 kasus. Tidak ada perbedaan umur pada kelompok kasus dan kontrol karena telah dilakukan matching terhadap umur.

Subyek menurut jenis kelamin, terlihat bahwa subyek penelitian yang banyak menderita malaria adalah perempuan yaitu sebanyak 49 kasus $(59,0 \%)$ dibanding dengan laki-laki yang hanya ditemukan 34 kasus $(41,0 \%)$. Sedangkan untuk kontrol perempuan berjumlah 51 orang $(61,4 \%)$ dan laki-laki berjumlah 32 orang $(38,6 \%)$.

Subyek kasus berdasarkan tingkat pendidikan, yang paling banyak adalah SMA yaitu sebanyak $42(50,6 \%)$ kasus, sedangkan tingkat pendidikan yang paling sedikit yaitu TS (Tidak Sekolah) yang berjumlah $2(2,4 \%)$ kasus . Subyek 
kontrol yang paling banyak adalah tingkat pendidikan SD yaitu sebanyak 30 $(36,1 \%)$ orang dan tingkat pendidikan yang paling sedikit yaitu PT (Perguruan Tinggi) dan TS (Tidak Sekolah) yang sama-sama berjumlah $1(1,2 \%)$ orang.

Karakteristik subyek penelitian berdasarkan pekerjaan terlihat bahwa untuk kelompok kasus jenis pekerjaan yang paling banyak adalah wiraswasta yaitu $32(38,6 \%)$. Kelompok kontrol pekerjaan yang paling banyak adalah IRT (Ibu Rumah Tangga) yaitu 32 (38,6\%).

2) Gambaran karakteristik subyek berdasarkan variabel penelitian

Tabel 3. Distribusi frekuensi karakteristik subyek menurut variabel penelitian di wilayah kerja Puskesmas Paruga tahun 2008

\begin{tabular}{|c|c|c|c|c|c|}
\hline No & Variabel & & Kasus & & Kontrol \\
\hline 2 & & Jumlah & Persentase (\%) & Jumlah & Persentase (\%) \\
\hline 10 & $\begin{array}{l}\text { Jarak rumah dengan tempat perindukan } \\
\text { nyamuk dan tempat peristirahatan nyamuk } \\
\text { a. Dekat } \\
\text { b. Jauh } \\
\text { Total }\end{array}$ & $\begin{array}{c}80 \\
3 \\
83\end{array}$ & $\begin{array}{c}96,4 \\
24,1 \\
100\end{array}$ & $\begin{array}{l}69 \\
14 \\
83\end{array}$ & $\begin{array}{c}83,1 \\
16,9 \\
100\end{array}$ \\
\hline 2 & $\begin{array}{l}\text { Pakai kelambu } \\
\text { a.Tidak } \\
\text { b.Ya } \\
\text { Total }\end{array}$ & $\begin{array}{l}48 \\
35 \\
83\end{array}$ & $\begin{array}{c}57,8 \\
42,2 \\
100\end{array}$ & $\begin{array}{l}48 \\
35 \\
83\end{array}$ & $\begin{array}{c}57,8 \\
42,2 \\
100\end{array}$ \\
\hline 3 & $\begin{array}{l}\text { Pakai obat anti nyamuk } \\
\text { a.Tidak } \\
\text { b.Ya } \\
\text { Total }\end{array}$ & $\begin{array}{l}29 \\
54 \\
83\end{array}$ & $\begin{array}{r}34,9 \\
65,1 \\
100\end{array}$ & $\begin{array}{l}16 \\
67 \\
83\end{array}$ & $\begin{array}{r}19,3 \\
80,7 \\
100\end{array}$ \\
\hline 4 & $\begin{array}{l}\text { Sering keluar malam } \\
\text { a.Ya } \\
\text { b.Tidak } \\
\text { Total }\end{array}$ & $\begin{array}{l}21 \\
62 \\
83\end{array}$ & $\begin{array}{r}25,3 \\
74,7 \\
100\end{array}$ & $\begin{array}{l}14 \\
69 \\
83\end{array}$ & $\begin{array}{r}16,9 \\
83,1 \\
100\end{array}$ \\
\hline 5 & $\begin{array}{l}\text { Pengetahuan } \\
\text { a.Tidak Tahu } \\
\text { b.Tahu } \\
\text { Total }\end{array}$ & $\begin{array}{l}45 \\
38 \\
83\end{array}$ & $\begin{array}{c}54,2 \\
45,8 \\
100\end{array}$ & $\begin{array}{l}31 \\
52 \\
83\end{array}$ & $\begin{array}{c}37,3 \\
62,7 \\
100\end{array}$ \\
\hline 6 & $\begin{array}{l}\text { Pernah mendapat penyuluhan } \\
\text { a.Tidak } \\
\text { b.Ya }\end{array}$ & $\begin{array}{l}63 \\
20 \\
\end{array}$ & $\begin{array}{r}75,9 \\
24,1\end{array}$ & $\begin{array}{l}64 \\
19 \\
\end{array}$ & $\begin{array}{l}77,1 \\
22,9 \\
\end{array}$ \\
\hline & Total & 83 & 100 & 83 & 100 \\
\hline
\end{tabular}

Karakteristik subyek penelitian di wilayah kerja Puskesmas Paruga terlihat bahwa jumlah kasus yang memiliki rumah dekat dengan tempat perkembangbiakan nyamuk dan tempat peristirahatan nyamuk sebayak 80 orang $(96,4 \%)$ dan yang memiliki rumah jauh dengan tempat perkembangbiakan nyamuk dan tempat peristirahatan nyamuk sebanyak 3 orang $(24,1 \%)$. Kelompok kontrol yang memiliki rumah dekat dengan tempat perkembangbiakan nyamuk dan tempat peristirahatan nyamuk sebanyak 69 orang $(83,1 \%)$ dan yang memiliki rumah jauh dengan tempat perkembangbiakan nyamuk dan tempat peristirahatan nyamuk sebanyak 14 orang $(16,9 \%)$.

Berdasarkan hasil penelitian di wilayah kerja Puskesmas Paruga terlihat bahwa jumlah kasus yang memakai kelambu sebayak 35 orang $(42,2 \%)$ dan tidak memakai kelambu sebanyak 48 orang $(57,8 \%)$. Kelompok kontrol yang memakai kelambu sebanyak 35 orang $(42,2 \%)$ dan tidak memakai kelambu sebanyak 48 orang $(57,8 \%)$. Jumlah kasus yang memakai obat anti nyamuk sebayak 54 orang $(65,1 \%)$ dan tidak memakai obat anti nyamuk sebanyak 29 orang $(34,9 \%)$. Kelompok kontrol yang memakai obat anti nyamuk sebanyak 67 
orang $(80,7 \%)$ dan tidak memakai obat anti nyamuk sebanyak 16 orang $(19,3 \%)$. Subyek kelompok kasus yang sering keluar malam sebayak 21 orang $(25,3 \%)$ dan tidak sering keluar malam sebanyak 62 orang $(74,7 \%)$. Kelompok kontrol yang sering keluar malam sebanyak 14 orang $(16,9 \%)$ dan tidak sering keluar malam sebanyak 69 orang $(83,1 \%)$.

Karakteristik subyek penelitian di wilayah kerja Puskesmas Paruga terlihat bahwa jumlah kasus yang tidak tahu tentang malaria sebayak 45 orang $(54,2 \%)$ dan yang tahu tentang malaria sebanyak 38 orang $(45,8 \%)$. Kelompok kontrol yang tidak tahu tentang malaria sebanyak 31orang $(37,3 \%)$ dan yang tahu tentang malaria sebanyak 52 orang $(62,7 \%)$.

Subyek penelitian untuk kelompok kasus yang pernah mendapat penyuluhan sebanyak 20 orang $(24,1 \%)$ dan tidak pernah mendapat penyuluhan sebanyak 63 orang (75,9\%). Kelompok kontrol yang pernah mendapat penyuluhan sebanyak 19 orang $(22,9 \%)$ dan tidak pernah mendapat penyuluhan sebanyak 64 orang $(77,1 \%)$.

\section{b. Analisis Bivariat}

Tabel 4. Hubungan antara variabel penelitian dengan kejadian malaria di wilayah kerja Puskesmas Paruga tahun 2008

\begin{tabular}{|c|c|c|c|c|}
\hline No & Variabel & OR & $P$ & Cl $95 \%$ \\
\hline 1 & $\begin{array}{l}\text { Jarak rumah dengan tempat perindukan nyamuk dan } \\
\text { tempat peristirahatan nyamuk }\end{array}$ & 5,41 & 0,01 & $1,38<\mathrm{OR}<24,81$ \\
\hline 2 & Pakai kelambu & 1,00 & 1,00 & $0,52<\mathrm{OR}<1,94$ \\
\hline 3 & Pakai obat anti nyamuk & 2,25 & 0,02 & $1,05<\mathrm{OR}<4,86$ \\
\hline 4 & Sering keluar malam & 1,67 & 0,18 & $0,73<\mathrm{OR}<3,82$ \\
\hline 5 & Pengetahuan & 1,99 & 0,02 & $1,02<\mathrm{OR}<3,88$ \\
\hline 6 & Pernah mendapat penyuluhan & 0.94 & 0,86 & $0,43<\mathrm{OR}<2,03$ \\
\hline
\end{tabular}

Orang yang memiliki rumah dekat dengan tempat perkembangbiakan nyamuk dan tempat peristirahatan nyamuk akan meningkatkan risiko terkena malaria sebesar 5,41 kali lebih besar dibandingkan dengan orang yang memilki rumah jauh dengan tempat perkembangbiakan nyamuk dan tempat peristirahatan nyamuk, dan secara statistik bermakna $(p=0,01)$. Kebiasaan menggunakan kelambu tidak bermakna secara statistik, dan secara biologik terhadap kejadian malaria. Analisis bivariat yang dilakukan diperoleh nilai $O R=1$ dengan $\mathrm{Cl} 95 \%$ $0,52<$ OR $<1,94$ dan nilai $p=1$. Tidak ada hubungan antara kebiasaan menggunakan kelambu dengan kejadian malaria. Orang yang tidak biasa menggunakan obat anti nyamuk sebelum tidur akan meningkatkan risiko terkena malaria sebesar 2,25 kali lebih besar dibandingkan dengan orang biasa menggunakan obat anti nyamuk sebelum tidur, dan secara statistik bermakna $(p=0,02)$.

Orang yang biasa keluar malam akan meningkatkan risiko terkena malaria sebesar 1,67 kali lebih besar dibandingkan dengan orang tidak biasa keluar malam, dan secara statistik tidak bermakna $(p=0,18)$. Orang yang tidak tahu tentang malaria akan meningkatkan risiko terkena malaria sebesar 1,99 kali lebih besar dibandingkan dengan orang tahu tentang malaria, dan secara statistik bermakna $(p=0,02)$. Penyuluhan tidak bermakna baik secara statistik maupun secara biologik terhadap kejadian malaria. Analisis bivariat yang dilakukan diperoleh nilai $O R=0,94$ dengan $C / 95 \% 0,43<O R<2,03$ dan nilai $p=0,855$. Hal ini berarti tidak ada hubungan antara penyuluhan dengan kejadian malaria. 


\section{c. Analisis Multivariate}

Tabel 5. Hubungan antara jarak rumah dengan tempat perkembangbiakan nyamuk, dan tempat peristirahatan nyamuk, kebiasaan menggunakan obat anti nyamuk dan pengetahuan dengan kejadian malaria di wilayah kerja puskesmas Paruga tahun 2008.

\begin{tabular}{llllll}
\hline \multirow{2}{*}{ No } & \multicolumn{1}{c}{ Variabel } & OR & Sig & \multicolumn{2}{c}{$95,0 \%$ CI for EXP(B) } \\
\cline { 3 - 6 } & & & & Lower & Upper \\
\hline $\begin{array}{l}\text { Jarak rumah dengan tempat perkembangbiakan } \\
\text { dan tempat peristirahatan nyamuk }\end{array}$ & 5,368 & 0,005 & 1,425 & 20,212 \\
\hline 2 & Pakai obat anti nyamuk & 2,432 & 0,016 & 1,159 & 5,104 \\
\hline 3 & Pengetahuan & 2,051 & 0,028 & 1,072 & 3,924 \\
\hline & Constant & 0,011 & 0,000 & & \\
\hline
\end{tabular}

Hasil analisis multivariat menunjukkan bahwa variabel yang sangat berhubungan dengan kejadian malaria adalah jarak rumah dengan tempat perkembangbiakan nyamuk dan tempat peristirahatan nyamuk dengan nilai signifikansi (Sig) sebesar 0,005.

\section{d. Pembahasan}

Pada penelitian ini usia pada kelompok kasus dan kontrol sama karena telah dilakukan matching. Usia 15-24 tahun merupakan prevalensi tertinggi terkena malaria. Hal ini disebabkan karena pada usia 15-24 tahun cenderung memiliki aktifitas yang tinggi terutama kegiatan di luar rumah, sehingga kemungkinan kontak dengan nyamuk lebih tinggi. Hal serupa juga dikemukakan oleh $^{6}$ yang menyatakan bahwa usia 15-24 tahun merupakan prevalensi tertinggi terkena malaria.

Distribusi kasus menurut jenis kelamin, malaria banyak terjadi pada perempuan. Hasil penelitian ini serupa dengan penelitian ${ }^{7}$ Arsin dkk yang menunjukkan kasus malaria lebih banyak terjadi pada perempuan dibandingkan dengan laki-laki. Hal ini disebabkan karena mobilitas yang rendah. Perempuan lebih banyak berdiam di rumah sehingga kontak dengan Anopheles lebih besar.

1) Jarak rumah dengan tempat perkembangbiakan nyamuk dan tempat peristirahatan nyamuk

Adanya genangan air di sekitar rumah dapat diperkirakan sebagai salah satu sumber perkembangbiakan nyamuk termasuk nyamuk vektor malaria. Dengan demikian orang yang tinggal di rumah yang disekitarnya terdapat genagan air mempunyai risiko lebih tinggi untuk menderita malaria. Nyamuk vektor malaria yang tumbuh dewasa digenangan air akan singgah dan beristirahat di tempat-tempat yang rimbun seperti hutan, perkebunan, semak-semak dan sebagainya. Oleh karena itu orang yang disekitar rumahnya terdapat tempat peristirahatan nyamuk mempunyai risiko digigit nyamuk malaria lebih tinggi dibandingkan orang yang disekitar rumahnya tidak terdapat tempat peristirahatan nyamuk ${ }^{6}$.

Dalam penelitian ini ditemukan subyek yang disekitar rumahnya terdapat tempat perkembangbiakan nyamuk dan tempat peristirahatan nyamuk untuk kelompok kasus sebanyak 96,4\% dan kelompok kontrol sebanyak $24,1 \%$. Berdasarkan hasil analisis tabulasi silang diketahui bahwa orang yang memiliki rumah dekat dengan tempat perkembangbiakan nyamuk dan tempat peristirahatan nyamuk akan meningkatkan risiko terkena malaria 
sebesar 5,41 kali lebih besar dibandingkan dengan orang yang memilki rumah jauh dengan tempat perkembangbiakan nyamuk dan tempat peristirahatan nyamuk, dan secara statistik bermakna $(p=0,01)$.

Di Kota Bima tempat perkembangbiakan nyamuk berupa pantai, sawah, tambak, sungai dan selokan-selokan yang pada musim-musim tertentu airnya tidak mengalir deras dan bahkan menggenang. Pada waktu air laut pasang, air akan mencapai sebagian rumah penduduk, sehingga akan menyebabkan adanya genangan air yang diperkirakan menjadi salah satu tempat perkembangbiakan bagi nyamuk malaria. Tempat peristirahatan nyamuk yang ada di tempat penelitian berupa hutan, semak-semak, hutan bakau, perkebunan kelapa dan sebagainya.

Penelitian yang sama juga dikemukakan oleh $\mathrm{Hadi}^{6}$ yang menyatakan bahwa orang yang disekitar rumahnya terdapat genangan air mempunyai risiko untuk menderita malaria 3,3 kali lebih tinggi dibandingkan orang yang disekitar rumanya tidak terdapat genangan air $(O P=3,3,95 \%$ $\mathrm{Cl}=2.0 ; 5.5)$. Dalam uji regresi berganda orang yang disekitar rumahnya terdapat tempat peristirahatan nyamuk mempunyai risiko untuk menderita malaria 4,8 kali lebih tinggi dibandingkan orang yang disekitar rumahnya tidak terdapat tempat peristirahatan nyamuk $(\mathrm{OR}=4,8,95 \% \mathrm{Cl}=2.6 ; 8.6)$.

2) Kebiasaan menggunakan kelambu.

Beberapa upaya telah dilakukan untuk menurunkan angka kejadian malaria. Salah satu upaya yaitu klambunisasi atau sosialisasi pemanfaatan kelambu tempat tidur. Dengan pemasangan kelambu pada tempat tidur dan menggunakannya pada saat tidur dapat mengurangi kontak individu dengan nyamuk malaria ${ }^{6}$. Selain itu pemakaian kelambu juga merupakan tindakan protektif dan cara paling konvensional yang bertujuan untuk mengurangi kontak vektor parasit-manusia untuk orang per orang atau pun keluarga dalam satu rumah. Dari segi epidemiologis malaria, esensi dan tindakan tersebut adalah cara untuk mencegah masuknya sporozoit parasit malaria lewat gigitan nyamuk vektor yang benar-benar siap tular (sporozoit parasit malaria benar-benar ada dalam kelenjar liurnya) ke dalam tubuh manusia yang akan menjadi korban gigitan nyamuk verktor malaria ${ }^{7}$.

Pemakaian kelambu pada subyek penelitian menunjukkan jumlah penderita positif malaria yang menggunakan kelambu pada waktu tidur berjumlah $35(42,2 \%)$ dan tidak menggunakan kelambu berjumlah 48 $(57,8 \%)$. Dari hasil tabulasi silang diperoleh $O R=1,00$ dan nilai $p=1,00$ yang berarti secara statistik kebiasaan menggunakan kelambu tidak berhubungan dengan kejadian malaria. Jumlah keluarga di daerah penelitian yang mempunyai kelambu dan mau menggunakan kelambu sangat sedikit. Sebagian besar masyarakat tidak mempunyai kelambu dengan alasan mahal untuk membeli. Sebagian tidak menggunakan kelambu dengan alasan tidak nyaman, misalnya merasa panas. Tidak mengherankan jika sering ditemukan adanya kelambu bantuan dari pemerintah lebih sering digunakan untuk kepentingan lain seperti untuk menjaring ikan di sungai ketimbang untuk mencegah/mengurangi kontak nyamuk di rumah. Dengan kata lain penggunaan kelambu bukan suatu cara yang efektif bisa diterapkan untuk menurunkan kejadian malaria di daerah endemis malaria di Kota Bima.

Hasil yang sama juga dikemukakan oleh Tahaharudin $\mathrm{dkk}^{8}$ yang menyatakan bahwa pemakaian kelambu pada waktu tidur bukan merupakan variabel yang dapat mempengaruhi kejadian malaria dengan nilai $p>0,01$

Berbeda dengan penelitian Pebrorizal ${ }^{4}$ yang dilakukan di provinsi Bengkulu yang menyatakan bahwa kebiasaan menggunakan kelambu pada 
waktu tidur memiliki hubungan terhadap kejadian malaria dengan nilai $(p=0,001)$. Hal ini sependapat dengan $\mathrm{Hadi}^{6}$ yang menyatakan bahwa orang yang menggunakan kelambu mempunyai risiko untuk menderita malaria 2,8 kali lebih rendah dibandingkan orang yang tidak menggunakan kelambu $(\mathrm{OR}=0,36,95 \% \mathrm{Cl}=0,1 ; 1,1)$. Waluyo ${ }^{9}$ menyatakan kebiasaan tidur menggunakan kelambu pada malam hari mempunyai hubungan yang sangat bermakna dengan kejadian malaria di Kecamatan Kokap. Penduduk yang tidak pernah menggunakan kelambu ketika tidup pada malam hari memiliki risiko terkena malaria 5,2 kali lebih besar dibandingkan dengan yang selalu menggunakan kelambu.

3) Kebiasaan menggunakan obat anti nyamuk

Salah satu cara lain untuk mengurangi risiko tergigit nyamuk malaria adalah menggunakan obat anti nyamuk terutama menjelang tidur sore ${ }^{8}$. Proporsi kasus yang biasa menggunakan obat anti nyamuk pada malam hari adalah $56,1 \%$ sedangkan kelompok kontrol yang biasa menggunakan obat anti nyamuk adalah $80,7 \%$.

Dari hasil tabulasi silang diketahui bahwa orang yang tidak biasa menggunakan obat anti nyamuk sebelum tidur akan meningkatkan risiko terkena malaria sebesar 2,25 kali lebih besar dibandingkan dengan orang biasa menggunakan obat anti nyamuk sebelum tidur, dan secara statistik bermakna $(p=0,02)$. Penggunaan obat anti nyamuk jika dibandingkan dengan dengan penggunaan kelambu menurut hasil wawancara di lapangan, pemasyarakatan penggunaan obat anti nyamuk tampaknya lebih mudah diterima oleh masyarakat dengan beberapa alasan sebagai berikut: obat anti nyamuk harganya lebih terjangkau dibanding kelambu, obat anti nyamuk tidak menimbulkan akibat-akibat yang kurang disukai, dan obat anti nyamuk tidak harus digunakan setiap saat/musim tetapi hanya pada bulanbulan tertentu saja.

Hasil penelitian ini sesuai dengan penelitian yang dilakukan oleh Hadi $^{6}$ yang menyatakan bahwa dari hasil uji regresi logistik berganda diketahui orang yang biasa menggunakan obat anti nyamuk mempunyai risiko menderita malaria 2,5 kali lebih rendah dibandingkan orang yang tidak biasa menggunakan obat anti nyamuk ( $(\mathrm{OR}=0,40,95 \% \mathrm{Cl}=0,24 ; 0,65)$. Berbeda dengan penelitian Pebrorizal ${ }^{4}$ yang dilakukan di provinsi Bengkulu yang menyatakan bahwa kebiasaan menggunakan obat anti nyamuk tidak memiliki hubungan terhadap kejadian malaria dengan nilai $p=0,887$ ).

4) Kebiasaan keluar malam

Kebiasaan untuk berada di luar rumah sampai larut malam, dimana vektor malaria bersifat eksofilik dan eksofagik akan memudahkan gigitan nyamuk $^{4}$. Proporsi kasus yang biasa keluar pada malam hari adalah 25,3 sedangkan kelompok kontrol yang biasa keluar pada malam hari adalah $16,9 \%$. Dari hasil tabulasi silang diperoleh $O R=1,67$ dan nilai $p=0,184$ yang berarti secara statistik kebiasaan keluar pada malam hari tidak berhubungan dengan kejadian malaria. Hal ini dimungkinkan karena masyarakat kota bima tidak mempunyai kebiasaan keluar rumah pada malam hari, karena kegiatan perekonomian di Kota Bima seperti pasar tradisional, toko-toko, pusat perbelanjaan melaksanakan kegiatannya mulai jam 08.00 wita sampai dengan 21.00. Kemaknaan biologis menyatakan bahwa orang yang sering keluar malam memiliki risiko menderita malaria 1,67 kali lebih tinggi dibandingkan orang yang tidak biasa keluar malam. Hal ini sesuai dengan teori yang menyatakan bahwa salah satu cara untuk menghindari diri dari 
gigitan nyamuk malaria yaitu dengan tidak berpergian antara senja dan malam hari karena pada watu itu umumnya nyamuk menggigit ${ }^{10}$.

Berbeda dengan penelitian Pebrorizal ${ }^{4}$ yang dilakukan di provinsi Bengkulu yang menyatakan bahwa kebiasaan keluar malam hari memiliki hubungan terhadap kejadian malaria dengan nilai $p=0,039$. Hasil penelitian ini sama dengan penelitian yang dilakukan oleh Tahaharudin dkk $^{11}$ yang menunjukkan bahwa keluar rumah pada malam hari mempunyai hubungan yang sangat bermakna dengan nilai $p=0,000$. Hal ini sependapat dengan Rizal $^{11}$ yang menyatakan bahwa kebiasaan di luar rumah malam hari merupakan faktor risiko yang berhubungan dengan kejadian malaria dengan nilai $p=0,000$.

5) Pengetahuan tentang malaria

Pengetahuan merupakan domain yang sangat penting untuk terbentuknya perilaku seseorang, termasuk diantaranya perilaku dalam upaya-upaya pencegahan dan pengobatan malaria. Persepsi yang keliru tentang penyabab dan cara penularan malaria dapat mengarahkan pada perilaku masyarakat yang tidak benar terutama pada upaya-upaya pencegahan dan pengobatan penyakit malaria ${ }^{12}$.

Subyek penelitian pada kelompok kasus yang tahu tentang malaria sebanyak 45,8\%, sedangkan pada kelompok kontrol sebanyak $62,7 \%$. Hasil tabulasi silang menunjukkan bahwa orang yang tidak tahu tentang malaria akan meningkatkan risiko terkena malaria sebesar 1,99 kali lebih besar dibandingkan dengan orang tahu tentang malaria, dan secara statistik bermakna $(p=0,02)$. Seperti halnya yang terjadi di daerah-daerah endemis malaria diberbagai wilayah di Indonesia, penyebab penyakit malaria tidak diketahui dengan benar oleh masyarakat di tempat penelitian. Secara keseluruhan, lebih dari $80 \%$ responden mengetahui bahwa malaria disebabkan oleh parasit yang dibawa oleh nyamuk malaria. Tetapi anehnya masih banyak juga responden yang beranggapan bahwa malaria disebabkan oleh makanan yang tidak bersih, udara kotor dan sebagian lagi masih menganggap bahwa malaria disebabkan oleh makhlus halus dan malaria merupakan penyakit keturunan. Beberapa pengetahuan yang ada di tengahtengah masyarakat yang dapat mengaburkan pemahaman tentang etiologi dan cara penularan malaria perlu diluruskan, sehingga masyarakat akan terhindar dari kerancuan dan ambivalensi yang dapat mengarahkan mereka pada perilaku yang tidak adekuat dalam upaya-upaya pencegahan malaria.

Hasil yang sama juga dikemukakan oleh Arsin dkk ${ }^{5}$ yang menyatakan bahwa tingkat pengetahuan masyarakat tentang malaria berhubungan dengan kejadian malaria dengan nilai $p=0,001$. Hal yang berbeda dikemukakan oleh Tahaharudin $\mathrm{dkk}^{11}$ yang menunjukkan bahwa tingkat pengetahuan masyarakat tentang malaria tidak mempunyai hubungan dengan angka kejadian malaria di Kota Sabang.

6) Penyuluhan tentang malaria

Penyuluhan sebagai bagian dari promosi kesehatan perlu dilakukan secara terpadu dalam starategi promosi kesehatan. Penyuluhan yang diperlukan adalah penyuluhan yang sesuai dengan kondisi setempat. Paket media yang digunakan untuk penyuluhan sebaiknya dipersiapkan agar benar -benar sesuai dengan sosial budaya setempat ${ }^{14}$. Selain itu penyuluhan merupakan salah satu cara yang perlu dipertimbangkan dalam pemberantasan vektor malaria yaitu penyuluhan kesehatan masyarakat 
secara massif dengan sasaran penduduk yang mempunyai risiko tinggi tertulari dengan cara melindungi diri terhadap penularan ${ }^{10}$.

Penelitian ini proporsi kasus yang pernah mendapat menyuluhan adalah $24,1 \%$ sedangkan kelompok kontrol yang pernah mendapat penyuluhan adalah 22,9\%. Dari hasil tabulasi silang diperoleh $\mathrm{OR}=0,94$ dan nilai $p=0,855$ yang berarti secara statistik dan biologik penyuluhan tentang malaria tidak berhubungan dengan kejadian malaria. Hal ini dimungkinkan karena tiap kali petugas dari Puskesmas Paruga turun kelapangan untuk memberikan penyuluhan tentang malaria hanya sebagian kecil masyarakat saja yang mengikutinya. Alasan masyarakat tidak mengikuti penyuluhan tersebut diantaranya: mereka cenderung lebih mementingkan pekerjaan ketimbang mengikuti penyuluhan, malas karena dianggap penyuluhan bukan merupakan hal yang penting bagi mereka.

Penelitian yang dilakukan oleh Santoso dkk $^{13}$ menunjukkan bahwa penyuluhan yang tepat guna yang diberikan kepada masyarakat daerah endemis malaria di Kecamatan Kokap dapat meningkatkan perubahan pengetahuan, sikap, dan perilaku secara bermakna pada kelompok intervensi. Peningkatan persentase pada kelompok sasaran berkisar, antara $10 \%$ sampai $80 \%$. Sedang pada daerah kontrol hanya sekitar $5 \%$ sampai $40 \%$ terutama pengetahuan tentang nyamuk malaria. Peningkatan yang terjadi pada kelompok kontrol kemungkinan karena adanya difusi dari daerah intervensi atau program rutin yang dilakukan oleh dinas kesehatan.

\section{SIMPULAN DAN SARAN}

a. Simpulan

1) Faktor lingkungan meliputi adanya tempat perkembangbiakan nyamuk dan tempat peristirahatan nyamuk di sekitar rumah terbukti sebagai faktor risiko terhadap kejadian malaria di wilayah kerja puskesmas Paruga Kota Bima.

2) Kebiasaan menggunakan obat anti nyamuk pada malam hari merupakan faktor risiko terhadap kejadian malaria di wilayah kerja puskesmas Paruga Kota Bima.

3) Tingkat pengetahuan penduduk tentang malaria merupakan faktor risiko terhadap kejadian malaria di wilayah kerja puskesmas Paruga Kota Bima.

b. Saran

1) Manajemen (modifikasi) lingkungan perlu dilakukan untuk mengendalikan kejadian malaria di wilayah kerja puskesmas Paruga Kota Bima.

2) Upaya untuk meningkatkan penggunaan obat anti nyamuk di masyarakat perlu dilakukan untuk menjadi salah satu bentuk intervensi dalam rangka pengendalian penyakit malaria di Kota Bima.

3) Pendidikan kesehatan dengan fokus pada pengetahuan yang benar tentang etiologi, cara penularan dan cara pencegahan malaria mungkin bisa menjadi salah satu kunci keberhasilan untuk meningkatkan peran serta masyarakat dalam upaya penanggulangan malaria.

\section{KEPUSTAKAAN}

1. Agustini,Widijanti Anik. Nilai Diagnostik Uji Imunokromatografi Pada Infeksi Malaria.Medika Jurnal Kedokteran dan Farmasi, Vol. XXX, Oktober, hal. 626-630.2000

2. Purnawan,Iwan. Malaria Falsiparum Dengan Kompikasi Gagal Ginjal Akut.Jurnal Kedokteran Trisakti, Vol. 19, No.1, hal. 1-5.2000 
3. Harijanto PN. Malaria: Epidemiologi, Patogenesis, Manifestasi Klinis dan Penanganannya. Jakarta : EGC.2000

4. Pebrorizal. Faktor-faktor Risiko Penularan Malaria Vivax di Kabupaten Bengkulu Selatan Provinsi Bengkulu. Skripsi. Yogyakarta: IKM Universitas Ahmad Dahlan.2007

5. Arsin A. Arsunan, at all. Analisis Perilaku Masyarakat Terhadap Kejadian Malaria di Pulau Kepoposang, Kabupaten Pangkajene Kepulauan Tahun 2003. Artikel Medika No 12 Tahun XXIX Desember, hal 762-768.2003

6. Hadi Hamam. Perilaku Manusia dan Lingkungan Sebagai Faktor Risiko Kejadian Malaria di Propinsi Jawa Tengah. Berita Kedokteran Masyarakat Volume 3 Nomor XVII, 157-169.2001

7. Mardihusodo Sugeng \& Juwono. Malaria: Status Kini dan Pengendalian Nyamuk Vektornya Untuk Abad XXI. Pidato Pengukuhan Jabatan Guru Besar pada Fakultas Kedokteran, Universitas Gajah Mada.2000

8. Thaharuddin, at all. Lingkungan Perumahan, Kondisi Fisik, Tingkat Pengetahuan, Perilaku Masyarakat dan Angka Kejadian Malaria di Kota Sabang. Jurnal Manusia dan Lingkungan, Vol. X1. No 3, November, hal 126-133.2004

9. Waluyo, Hestu. Hubungan Faktor-faktor Pengetahuan Persepsi dan Perilaku Penduduk dengan Kejadian Malaria di Kecamatan Kokap Kabupaten Kulon Progo. Thesis. Yogyakarta: Program Pascasarjana IKM Universitas Gajah Mada.1995)

10. Kandun Nyoman. Manual Pemberantasan Penyakit Menular, Bakti Husada, Jakarta.2000

11. Rizal. Hubungan Tindakan Pencegahan Keluarga/Individu dengan Kejadian Malaria di Wilayah Kerja Puskesmas Tanjung Uban. Skripsi. Yogyakarta: IKM Universitas Ahmad Dahlan. 2000

12. Hadi Hamam. Kepercayaan dan Pengetahuan Masyarakat Tentang Malaria;Implikasi Bagi Program Pencegahan Malaria. Berita Kedokteran Masyarakat, Volume 4 Nomor XVII, 197-208. 2001

13. Santoso, at all. Penyuluhan Tepat Guna yang Berkaitan dengan Penyakit Malaria Bagi Penduduk Hargotirto Kecamatan Kokap, Kabupaten Kulon Progo, di Yogyakarta. Media Litbang Kesehatan Volume XII No.3, hal. 1-11. 2002

14. Lemeshow, Stanley. Besar Sampel dalam Penelitian Kesehatan Gadjah Mada University. Yogyakarta.1997 
